\title{
FACTORS INFLUENCING THE LEARNING SUCCESS OF MASTER STUDENTS AT IPB BUSINESS SCHOOL (SB-IPB)
}

\section{Maya Wulan Arini"), DS Priyarsono**), and Rokhani Hasbullah***)}

\author{
*) School of Business, Bogor Agricultural University \\ SB IPB Building, Pajajaran Road, Bogor, Indonesia 16151 \\ ${ }^{* *}$ Department of Economics, Faculty of Economics and Management, Bogor Agricultural University \\ Agatis Road, IPB Darmaga Campus, Bogor 16680
}

${ }^{* * *)}$ Department of Mechanical and Biosystem Engineering, Faculty of Agricultural Technology Bogor Agricultural University IPB Darmaga Campus, PO Box 220, Bogor 16002

\begin{abstract}
Business School of IPB (SB-IPB) has a low level of completing of study for its master program students on-time. Based on the report of $S B-I P B$ 2015, only $0.8 \%$ of students graduating in 2014/2015 successfully completed their study in the normal time of thesis writing. This study aims to identify what factors cause the students unable to complete their thesis on time, thus affecting their learning success. The primary data in this study came from interviews to the students of year 2011/2012, while the secondary data were obtained from the academic section of SB-IPB. Determination of the number of samples was done using slovin formula obtaining 80 students as the respondents. The data analysis method used was SEM with PLS method. The results of the research indicate that the indicator that has a dominant role on the student characteristics is employment status while the dominant role indicators on the process of thesis writing are the suitability of area of interest and the administrative process. The value of the characteristics of students significantly affecting the process of their thesis writing is-0.283, and this indicates that students who are full time workers have a number of constraints in their thesis writing process. Likewise, the process of the thesis writing has a significant influence on the success of the study i.e. 0.346, and it means that the easier the process of thesis writing, the greater the success of their study. The academic division is expected to be more active in controlling the students who are in the process of writing their thesis, especially for the class whose students work full time so that it can well support the learning success of the students.
\end{abstract}

Keywords: business school, master program, success of the study, PLS, SEM

\begin{abstract}
ABSTRAK
Mahasiswa program magister di sekolah bisnis IPB (SB-IPB) memiliki tingkat ketepatan penyelesaian studi yang masih rendah. Berdasarkan laporan SB IPB 2015, hanya 0.8\% mahasiswa yang lulus tahun 2014/2015 berhasil menyelesaikan studi dalam waktu normal penyusunan tesis. Penelitian ini bertujuan untuk mengidentifikasi faktor-faktor apa saja yang menyebabkan mahasiswa terlambat menyelesaikan tesis yang berdampak pada keberhasilan studi. Data primer dalam penelitian ini bersumber dari wawancara kepada mahasiswa tahun angkatan 2011/2012, sedangkan data sekunder bersumber dari bagian akademik SB-IPB. Penentuan jumlah sampel menggunakan rumus slovin diperoleh 80 mahasiswa sebagai responden. Metode analisis data yang digunakan, yaitu SEM dengan metode PLS. Hasil penelitian menunjukkan bahwa Indikator yang berperan dominan terhadap karakteristik mahasiswa yaitu status pekerjaan, sedangkan indikator yang berperan dominan terhadap proses penyusunan tesis yaitu kesesuaian bidang minat dan proses administrasi. Karakteristik mahasiswa signifikan memengaruhi proses penyusunan tesis sebesar -0.283. Artinya, mahasiswa yang aktif bekerja akan menghambat proses penyusunan tesisnya. Demikian juga proses penyusunan tesis berpengaruh signifikan pada keberhasilan studi sebesar 0.346. Artinya, semakin mudah proses penyusunan tesis maka akan semakin menigkatkan keberhasilan studi. Divisi akademik diharapkan dapat lebih aktif mengontrol mahasiswa yang sedang dalam proses penyusunan tesis terutama pada kelas yang mayoritas aktif bekerja untuk menunjang keberhasilan studi mahasiswa yang lebih baik.
\end{abstract}

Keywords: sekolah bisnis, program magister, keberhasilan studi, PLS, SEM

\footnotetext{
${ }^{1}$ Corresponding author:

Email: arienwulan@gmail.com
} 


\section{INTRODUCTION}

Business schools in Indonesia are widely implemented by various universities as the study program of the Master of Management. Implementation of business school (MM program) in Indonesia is the adoption of the MBA program implemented in various universities abroad. The MBA program abroad, motivated by the desire of business actors, entrepreneurs and CEOs, is conducted to deepen students' knowledge and expertise in accordance with the field of the business they run.

IPB Business School (SB-IPB) is one of the best business schools in Indonesia, and this school successfully managed to get the 1st rank in the CIVETS countries (Webometrics, 2016). The CIVETS consists of six countries that have business management schools, namely, Columbia, Indonesia, Vietnam, Egypt, Turkey, and South Africa. Based on the Rector Decree Number 5/IT3/OT/2015 the scope of the SB-IPB implementation covers Undergraduate Business Program (S1), Business Master Program (S2) and Business Doctoral Program (S3).

Most SB-IPB students are currently in the Master Program. The SB-IPB Master program is divided into three classes: regular, executive class (E) and special executive class (SE), and their students have different kinds of talents, interests, competencies, and motivations. The students' success or failure can be seen from their learning achievement. Obviously, to obtain a Master degree requires a normal time of 2 years; however, in practice, the students cannot always complete their studies on time, and some of them even resigned from the school. Table 1 shows the percentage of graduate students of SB-IPB in 2011 and 2012 which decreased from $77.07 \%$ to $75.09 \%$ while the number of students who resigned was higher during the process of thesis writing. This can degrade the performance of SB-IPB and should be an evaluation for the academic to improve the success of the study of the students.

Table 1. Percentage of graduate students of SB-IPB Batch 2011-2012

\begin{tabular}{lcc}
\hline \multirow{2}{*}{\multicolumn{1}{c}{ Description }} & \multicolumn{2}{c}{ Batch } \\
\cline { 2 - 3 } & 2011 & 2012 \\
\hline Graduated & 77.07 & 75.09 \\
Resigned from study & 7.32 & 11.19 \\
Resigned from thesis & 15.61 & 13.72 \\
\hline
\end{tabular}

Note: $\mathrm{N}$ batch $2011=205 ; \mathrm{N}$ batch $2012=277$
The success of a university can be measured from input, process, and output. One indicator of the university output is the learning success of its students. The length of the study period is one of the criteria to assess the quality of students and the standard of the students' success during their learning process in SB-IPB. The normal study period of students who complete their study on time is based on the calculation of the study period consisting of the quarter period of lectures (three months), and the thesis writing period (six months) conducted by the Academic Division.

Guillory (2008) reveals that one measure of performance in a higher education is the level of accuracy of the study period. Performance measurement can be performed by looking at achievements at a given time compared to targets and baselines (Frihadian et al. 2016). Figure 1 shows the target of the Academic Division for the normal period of thesis writing (six months) was only met by $0.8 \%$ of the students, indicating that $99.2 \%$ of the students of Batches 2011 and 2012 exceeded the specified normal time. Study completion time exceeding the time standard has a negative impact not only for students but also for other related parties such as the university, supervisors, and sponsoring parties (Siregar, 2015). Students who are late in completion of the thesis will rush in completing their thesis to use the rest of the time (deadline for drop out), thus reducing the quality of their research. The delay in completion of this thesis may also result in increased opportunity for students to drop out, thus declining SB-IPB performance. The school needs to evaluate the management of students who are in the process of preparing their thesis so that its performance can be improved.

There are several studies that become benchmarks for this research. First, a recent literature study by Jones (2013) revealing that issues often discussed in postgraduate studies include failure in on time completion of study, relationship with supervisors, supervision quality, and social isolation. Bain et al. (2009) examined the students who successfully completed their studies on time in order to find out what factors supported the success of their studies. This study was based on a survey on graduate students and was divided into two parts: participant profile and personal factors. The research indicates that the factors that influence the success of the students' study include important role of supervisors, financial support, and community connectedness with their classmates, lecturers and department, and graduate programs are 
also considered to be very important. The implications of this research are useful in determining the quality of the graduate program, strategies that can be developed to create and maintain a community of connectedness for students, role of professors in overall students' success, and initiatives to sustain the success of the graduate students.

Secondly, Oonyu and Wamala (2012) identified the final exam phase of the master program students as the cause of the delayed completion at Makerere University. The research found that strong administrative support systems are essential in assisting the timely completion of the study of the postgraduate students, especially on aspects related to the review process of the students' reports to ensure the timely completion of the study.

Thirdly, another research was also conducted to find ways to detect early signs of students who are experiencing difficulties and how to handle the problem (Manathunga, 2005). The results of the study mentioned that the supervisor has a great role. If the supervisors are able to adopt the focus of pedagogy in the guidance, to provide personal guidance and individual supervision on a regular basis, to build student confidence and to provide access to research culture, they should be able to detect early signs of students who are experiencing difficulties.

Fourthly, from the survey method conducted by Spaulding and Szapkiw (2012) on doctoral students at a private university in USA, it was found that the selection of research topics is one of the most challenging processes in dissertation writing. Another problem is the difficulty in finding time to work on the dissertation since a great amount of time will be spent in the dissertation work, as well as the difficulty in balancing time. From the results of interviews, it was also found that in general the study period of a university is very organized; however, when students start their dissertation writing phase, they should be more self-regulating, arrange meetings with their supervisor, in other words, there is less control from the management.

Fifthly, another research through the previous literature studies was also conducted by Jinarek (2010), mentioning that there are 3 groups of factors that contribute to the completion of research and timely dissertation writing completion. These factors are: 1 ) the quality and personal situation of the students including academic capacity, financial situation, language skills, interpersonal skills, and perseverance vs. self-sabotage behavior (Kearns et al. 2008); 2) the nature and quality of supervision, including the frequency of meetings, supports from other students and research colleagues, and 3) resources and facilities available for the project/ research (e.g. cultural collections, analytical facilities, required skills, and etc.). The three factors are synergistic in order to produce a timely completion of the study. In addition, Pitchforth et al. (2012) found that the four main factors that affect the timely completion of studies at Queensland University of Technology include personal aspects, research environments, research projects, and incoming skills. A university is in principle the same as a "company", indicating that in running their activities, colleges and companies use a number of "inputs" to produce some "outputs" (Wibowo, 2013). Business process in university has two functions, namely, main function and supporting function (Yunis and Surendro, 2009). Students are at the core of university business processes that are important to manage as well as possible. The low learning success of the students will adversely affect the performance of SB-IPB. This study aims to identify the factors that influence the success of SB-IPB Master students based on the business process of the school. The conceptual model developed in the study refers to the main functions of the school business process, starting from the inputs of new students, process of thesis writing and outputs of the students' success.

The scope of this research included the students of the SB-IPB Master program of E, SE and R classes of 2011 and 2012. The research was conducted in the scope of study of student input characteristics, and internal and external factors of students during the process of thesis writing that influenced the success of their study.

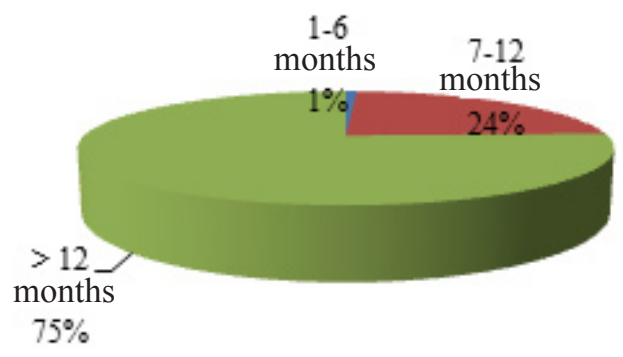

Figure 1. Percentage of students with the category of time length in thesis preparation 


\section{METHODS}

The research was conducted at SB-IPB campus located at Jl Padjajaran, Bogor. The selection of SB-IPB as the object of the research was determined purposively based on the existing problems, considering that SBIPB is one of the best universities running the Business Management Master program in Bogor, and the availability of campus management so that its internal and external strategies could be studied. The research activities were conducted from April 2016 to August 2016.

The research methods used in this research were qualitative and quantitative analyses with a case study approach. The case study is a detailed study on a person or unit over a period of time (Sevilla et al. 1993). The purpose of the case study is to provide a detailed figure on background, characters, and characteristics of the subject.

This research used the primary and secondary data as shown in Table 2. The primary data were obtained through questionnaires and interviews to the Masters students, and the secondary data were sources of information to completely answer the problems studied and related data or documents owned by SBIPB. The research was also supported by the data of literature studies, scientific journals and results of researches previously conducted relevant to the objects or problems being studied. These data were raw data that had to be processed first before being used for the specific purposes that suit the needs.
Data and information collections in this research were obtained by observations, interviews using questionnaire, and literature study. The selection of respondents was conducted by purposive sampling technique to select the students graduating in 2014/2015 i.e. batches of 2011 and 2012. These batches were chosen because it is considered that the graduates still had a strong memory on their thesis writing process. The total of the graduates of batches 2011 and 2012 reached 366 people. The number of samples in this study was 80 students selected using a slovin formula with an error of $10 \%$.

The measurement scale used in this research was Likert scale. Likert scale is used to measure students' perceptions and attitudes during the process of thesis writing. Tests on the validity and reliability of the questionnaire were performed to ensure that the compiled indicators were able to measure the variables to be observed.

The Analysis method to answer the purpose of identifying the factors that influenced the success of the SB-IPB master program students was the Structural Equation Modeling (SEM)-PLS. Partial Least Squares (PLS) is a powerful method of analysis and is often referred to as soft modeling because it negates OLS (Ordinary Least Square) assumptions such as regression. SEM-PLS usually consists of two sub-models, namely, the measurement model or outer model and the structural model or inner model (Ghozali, 2008). The measurement model in this study used 19 indicators that reflected the three latent variables (student characteristics, thesis writing process and study success).

Table 2. Data types and sources

\begin{tabular}{|c|c|c|c|}
\hline Data/information & Data Sources & Data Types & Analysis Method \\
\hline $\begin{array}{l}\text { Characteristics of input of the Master Pro- } \\
\text { gram Students of SB-IPB }\end{array}$ & $\begin{array}{l}\text { Documents of SB- } \\
\text { IPB and surveys by } \\
\text { questionnaire }\end{array}$ & $\begin{array}{l}\text { Primary and } \\
\text { Secondary Data }\end{array}$ & Descriptive \\
\hline \multicolumn{4}{|l|}{ Factors influencing the success of study: } \\
\hline $\begin{array}{l}\text { - Internal and external factors experienced } \\
\text { by the students in the thesis writing process }\end{array}$ & $\begin{array}{l}\text { Surveys by } \\
\text { questionnaire }\end{array}$ & Primary Data & $\begin{array}{l}\text { Structural Equation } \\
\text { Modeling (SEM) with PLS }\end{array}$ \\
\hline $\begin{array}{l}\text { - Indicators of the Learning Success of the } \\
\text { students in the Master Program of SB-IPB }\end{array}$ & Documents of SB-IPB & Secondary Data & $\begin{array}{l}\text { Structural Equation } \\
\text { Modeling (SEM) with PLS }\end{array}$ \\
\hline \multicolumn{4}{|l|}{ - GPA } \\
\hline - Study Period & & & \\
\hline
\end{tabular}


This research was divided into three stages: input, process and output. The input stage included the characteristics of students accepted in the SB-IPB Master program i.e. age, marital status, employment status, origin of S1 University, education cost source, S1 GPA, TPA score and TOEFL score. The phase of thesis writing process consisted of physical condition, motivation, suitability, interest area, family support, environmental condition, academic service, administrative process, academic policy, and supervisor role. Meanwhile, at the output stage, the indicators of the success of the study of the Masters students included GPA and study period. The initial stage of this research analyzed the relationship between the input characteristics of the SBIPB Master program students and the duration of thesis writing. In the following stage, the factors influencing the success of study of the SB-IPB Masters students were analyzed. The final stage is implementing the strategies in an effort to improve the success of study of the Masters students. The framework of the research can be seen in Figure 2 in detail.

Hypothesis to be tested in this research are:

$\mathrm{H} 1$ : the input of the student characteristics significantly influences the thesis writing process

$\mathrm{H} 2$ : the thesis writing process is significantly influential on the output of the students' learning success

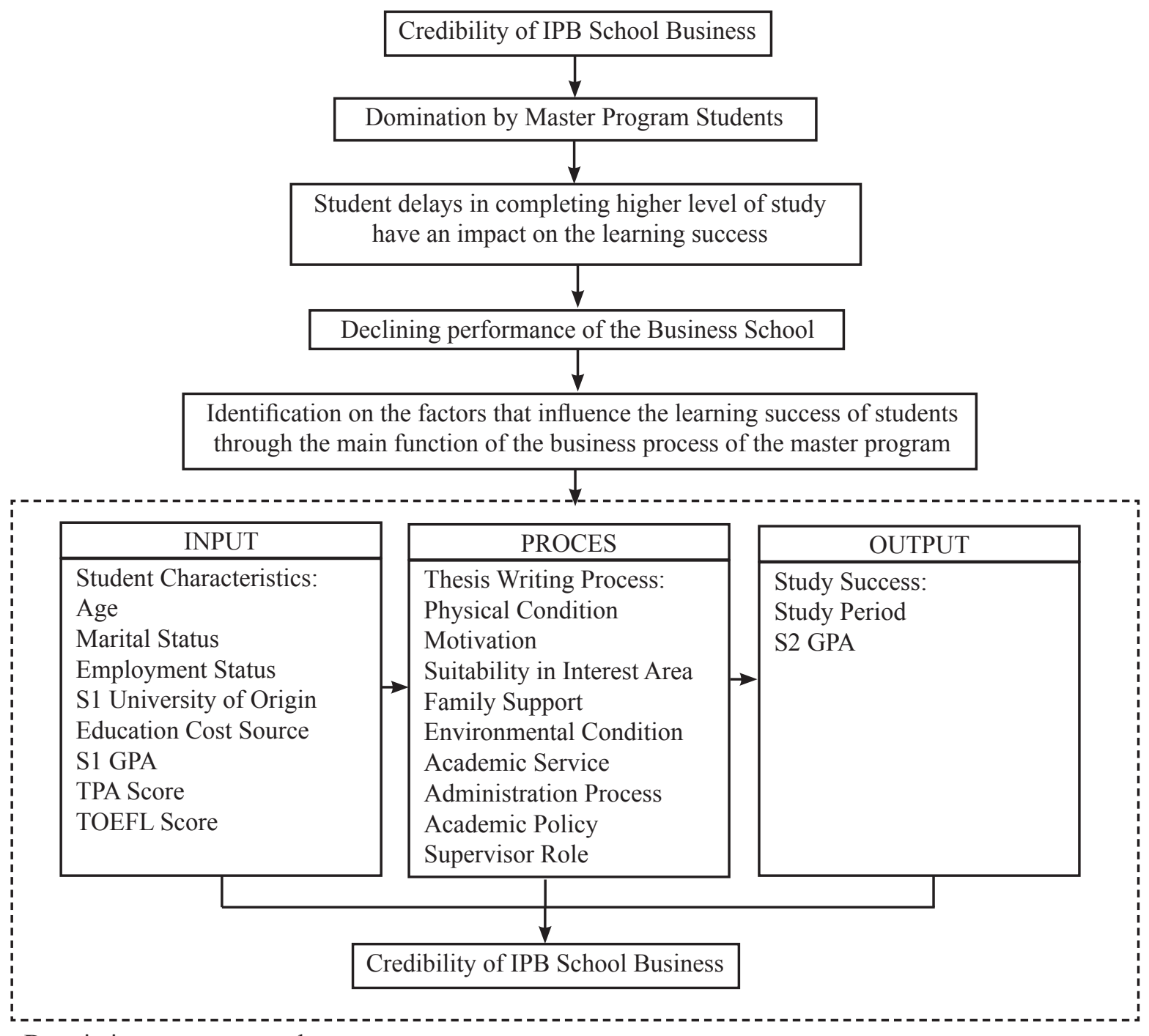

Description: ------ research scope

Figure 2. Research framework 


\section{RESULTS}

\section{Characteristics of Respondents}

Data were collected from the 80 SB-IPB students who graduated in 2014 or 2015 i.e. $57.5 \%$ of the respondents came from the executive class, while the rest came from the special executive class and regular class of $21.25 \%$ each. Based on sex, the male respondents reached a percentage of $52.5 \%$ and the female ones reached $47.5 \%$. Age of the respondents ranged dominantly between 23 and 32 years (61.25\%), while $31.25 \%$ of them aged $33-43$ years, and the rest (7.5\%) aged more than 43 years.

The survey results showed that most of the students $(51.2 \%)$ had their own initiative to continue studying in the Master Program of SB-IPB. Recommendation from work place or company was $20 \%$, recommendation from friends was $15 \%$, and recommendation from family was $11.2 \%$ while recommendation from the lecturers was only $2.5 \%$. In addition, in general, the sources of education cost of the respondents were obtained independently as much as $47.5 \%$, from the family as much as $28.8 \%$, and from the scholarship as much as $16.2 \%$ while $7.5 \%$ of the respondents obtained the fund from their workplace or company.

During their study, most respondents resided in Bogor (76\%), while the remaining $24 \%$ resided outside Bogor. Based on the residency type, $38 \%$ of the respondents lived in their own house, $36 \%$ of them lived in a boarding house or a rented house whereas $26 \%$ of them lived with their parents or relatives. In addition, $85 \%$ of the respondents still worked fulltime while studying at SBIPB while $15 \%$ of them did not work while undertaking their study at SB-IPB. Some respondents (52.5\%) worked as private sector employees, $16.2 \%$ worked as civil servants, and $8.8 \%$ worked as entrepreneurs. The least percentage of $7.5 \%$ said that they worked at the state-owned companies.

Based on the results of the analysis, it appears from the list of warning period that the respondents (34\%) had the obligation to pay fine weekly, $31 \%$ of them had to pay fine monthly and $18 \%$ of them got a warning to pay fine for their study renewal or until they reached the deadline for drop out. Moreover, $17 \%$ of the respondents stated that they did not receive a warning period list to pay fine.

\section{Factors Affecting Successful Learning}

Partial Least Squares (PLS) is a powerful analysis method and is often referred to as soft modeling because it eliminates the assumptions of the Ordinary Least Square (ICS) such as regression. SEM-PLS usually consists of two sub-models i.e. measurement model or outer model and structural model or inner model. The measurement model shows how the variables manifest or how the observed variables represent the variables to be measured while the structural model shows the strengths between among latent variables or constructs.

\section{Evaluation on Measurement Models}

Evaluation on the measurement model begins by looking at the loading factor value of each latent construct. If there is an indicator that has a loading factor value of $<0.5$, it should be recalculated against the initial model so that all reflective indicators produce a loading factor of $>0.5$ as the criterion of the validity test of the latent convergent constructs (Ghozali, 2008). Figure 3 shows that there is an indicator that has a loading factor value of $<0.5$; therefore, it is necessary to re-iterate the model.

After several iterations, the final model was obtained. Figure 4 shows that all indicators had a loading factor value $>0.5$. The student characteristic indicator in their influence on the process of thesis writing is only reflected by the employment status whereas the results of previous studies consistently state that the S1 GPA is the key predictor in determining the academic performance (Trail et al. 2006). This shows that the characteristic of business school students was more dominated by employment status than by S1 GPA in influencing the process of thesis writing. In addition, the final measurement model also shows that the physical condition, motivation, suitability of interest area, administrative process, academic policy and role of supervisors are significant in reflecting the process of thesis writing which influences the success of the study of the students.

The results of this study are also supported by Kusnendar et al. (2013) who show that the most dominant factors that hamper the completion of students' study include the factors of supervision with the supervisors, family, classmates, student reference, and administration. In addition, Frihadian et al. (2016) also states that, in 
P-ISSN: 2407-5434 E-ISSN: 2407-7321

Accredited by Ministry of RTHE Number 32a/E/KPT/2017
Available online at http://journal.ipb.ac.id/index.php/ijbe

DOI number: 10.17358/IJBE.3.2.90 general, another factor that plays a role in determining the success of the study is the motivation of the students themselves. Moreover, positive socialization and relationship with supervisors can prove to encourage students' retention and success (Barnes, 2010). This study shows the most dominant factors in reflecting the thesis writing process in influencing the success of the study of the students included the suitability of area of interest and administrative process with values of 0.882 and 0.808 respectively. There were 2 reflective indicators from the dimension variable of success of the study i.e. GPA S2 and study period. The highest indicator that reflects success of the study was the study period with a value of 0.936 .

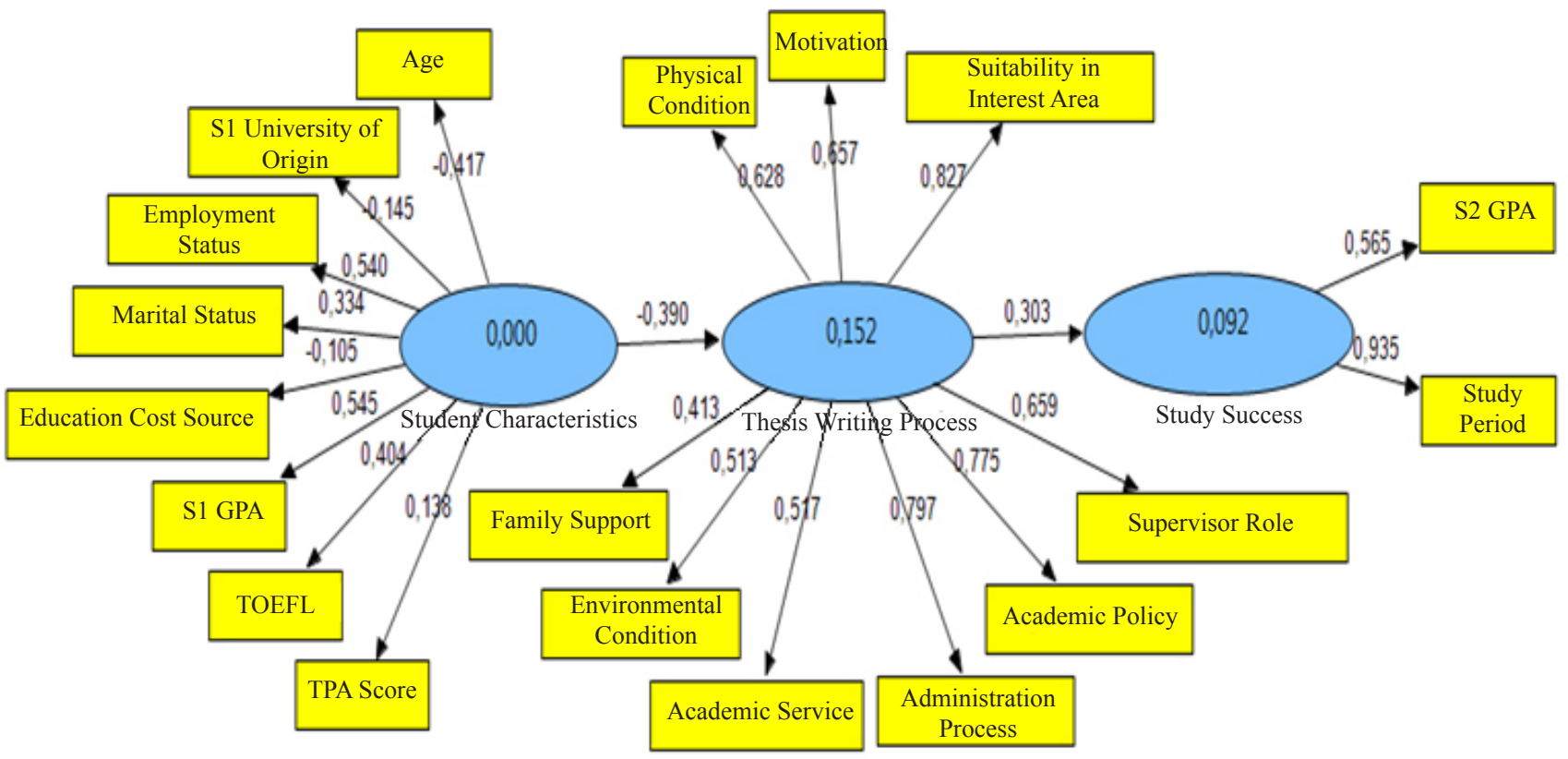

Figure 3. Loading factor on the initial measurement model

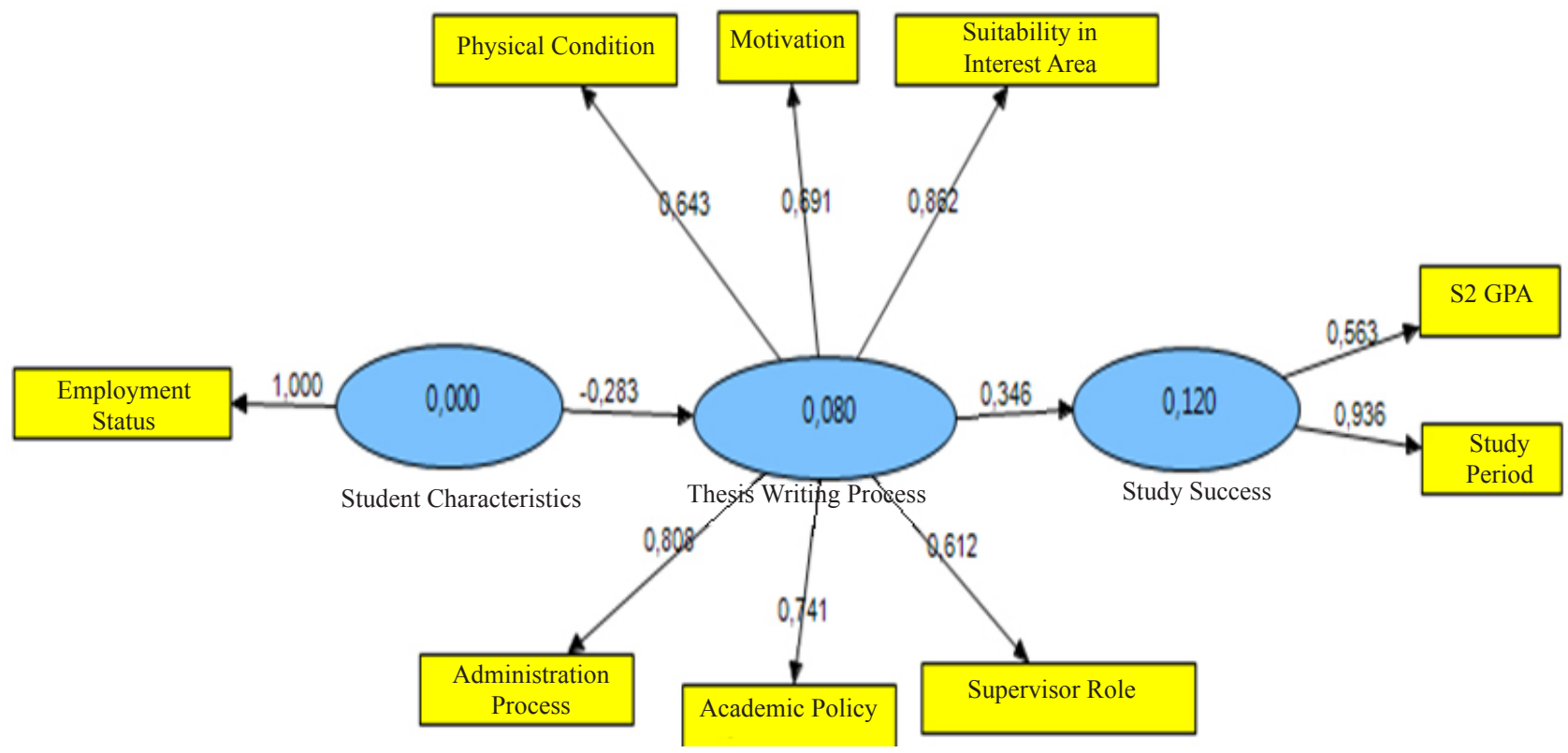

Figure 4. Loading factor on the final measurement model 
The second test for the convergent validity was performed by looking at the Average Variance Extracted (AVE) value on the reflective indicator model. The requirement for a model to have good validity is if each latent variable with its reflective indicator has an AVE value above 0.5 . The result of the analysis seen in Table 4 shows that the AVE value of each latent variable was $>0.5$; therefore, it can be said that the PLS model meets the requirements of good convergent validity.

The next measurement is the reliability test on the model used to prove the accuracy, consistency, and accuracy of the instruments in measuring the constructs. The first reliability test was to measure the composite reliability of the latent variables that had reflective indicators, and it was said to be reliable if the test value was greater than 0.6. The results based on Table 4 show that all latent constructs had good reliability, accuracy and consistency as they were qualified with the composite reliability values on each latent construct i.e. more than 0.6 .

Discriminant validity test is conducted on the principle that different construct manifest variables should not be highly correlated (Ghozali, 2008). Table 5 shows that the correlation values among the constructs were less than those of $\sqrt{A V E}$; therefore, it can be said that the model had met the requirements of discriminant validity.

\section{Evaluation on the Structural Model}

The inner model was then measured by bootstrapping in the final outer model by looking at the T-statistic value as a reference for evaluation in order to test the hypothesis on each path from the exogenous variables to the endogenous variables. The result of bootstrapping in Table 6 shows that the two paths had significant influences (T-statistic $>$ T-table of 1.96 at 5\% of real level). Characteristics of students significantly influence the process of thesis writing with a value of T-statistics of 3.80. Likewise, the thesis writing process had a significant influence on the learning success with a T-statistics value of 5.12. The structural model of the success of the study resulted in an R square value of $12 \%$, indicating that the success of the study in regards to the thesis writing process was $12 \%$ while the remaining $88 \%$ was explained by the other factors outside the model.

The value of the characteristics of students negatively affect the process of thesis writing was -0.28 , indicating that the characteristics of students reflected by students who were active in work would hamper the process of thesis writing and indirectly would also have an impact on the decrease of quality of the successful learning (Table 6). Also, the variable of thesis writing had a direct positive impact on the success of the study. The value of 0.35 indicates that if the process of thesis writing becomes better, it will increase the learning success as reflected by higher GPA and faster study period.

After identifying the factors influencing the learning success of the students, SB-IPB needs to select of the right business continuity management (BCM) strategy by managing the organizational changes. Changes in various institutions or organizations are required for an organization or institution to survive.

Table 4. Average variance extraxted (AVE) value and composite reliability value

\begin{tabular}{lcc}
\hline \multicolumn{1}{c}{ Variable } & AVE & Composite reliability \\
\hline Student characteristics & 1.00 & 1.00 \\
Success of study & 0.60 & 0.74 \\
Thesis writing process & 0.54 & 0.87 \\
\hline
\end{tabular}

Table 5. Matrix of Correlation among the latent variables

\begin{tabular}{lccc}
\hline & Student characteristics & Success of the study & Thesis writing process \\
\hline Student characteristics & $\sqrt{ } \mathrm{AVE}=1$ & & \\
Success of the study & -0.30 & $\sqrt{ } \mathrm{AVE}=0,77$ & \\
Thesis writing process & -0.28 & 0.35 & $\sqrt{ } \mathrm{AVE}=0.73$ \\
\hline
\end{tabular}

Table 6. Values of loading factor and t-statistics

\begin{tabular}{lcc}
\hline & Loading factor & T Statististics \\
\hline Student characteristics $\rightarrow$ Thesis writing process & -0.28 & 3.80 \\
Thesis writing process $\rightarrow$ Learning success & 0.35 & 5.12 \\
\hline
\end{tabular}


Change management is a systematic process of applying knowledge, facilities and resources required to influence changes in people who are affected by the process (Nasution, 2010). Change management is aimed at delivering business solutions successfully in an organized manner and method by managing the impacts of changes on the people involved.

Education is a process that is required to grow, following changes and developments of the environment (Laila, 2016). The research by Mircea and Andreescu (2011) explains that the changes made by universities should be oriented towards services provided to stakeholders and use of cloud computing systems/applications. In addition to these two issues, it is also important to consider critical issues that may occur, such as resistance to change; acceptance of a centralized budgeting model to support a new approach (since services are available across universities, not owned by a single department); and acknowledge that universities can design their yearly program implementation since their orientation is towards services to stakeholders; therefore, it can be predicted that in the long-term they will gain benefits.

Organizational change contributes to the effectiveness of work which means that any increase in the organizational change of one unit will affect the increase of work effectiveness (Yudhaningsih, 2011). Cultures or customs have implications for speed and accuracy in work completion. SB-IPB needs to conduct change management through the process management in the preparation stage of thesis writing to improve the success of the study of the students, thus giving an impact in improving the performance of SB-IPB. Based on the research results by Sujova and Rajnoha (2012), the realization of change management strategies through the implementation of process management components makes it possible to achieve improved business performance. After the change management as a first step to determine the right business continuity management (BCM) strategy, SB-IPB needs to develop $\mathrm{BCM}$ culture to raise awareness of $\mathrm{BCM}$ through communication design, training and socialization integrated with the organizational strategies. The final stage of the BCM cycle is conducting periodic audit processes on the implementation of the BCM strategy.

\section{Managerial Implications}

For the sake of achieving the vision of the new SB-IPB mission, it is also necessary to change management from organizational culture so far. To achieve the optimum development of universities, it is necessary to focus on changes or continuous improvement, i.e. systematic improvement process and implemented by strategic measures (Swartling and Poksinska, 2013).

SB-IPB needs to understand the characteristics of its current students so that the organizational management can meet the needs of students in supporting the success of their study. Postgraduate students have uniqueness and diversity that include: (1) age; (2) culture; (3) experience and ability; (4) part-time, full-time, internal and external students; (5) change of their needs over time, place, space; and (6) generally no supports from scholarships or from other funding sources (Abiddin and Ismail, 2011). Students enrolled in SB-IPB especially the Master program students have characteristics in general as business actors, entrepreneurs as well as managers of companies that work full time.

Characteristic of fulltime working students is mostly from the executive/special executive classes rather than from the regular class; therefore, it is necessary to distinguish treatments during the thesis writing preparation. The study period of the special executive/ executive classes tends to be longer i.e. 15 months compared to the regular classes of 12 months, while the normal time for completion of thesis is the same i.e. 6 months. The normal period of the thesis preparation for executive/special executive classes is also differentiated from the regular classes i.e. 9 months for E/ SE classes and 6 months for regular classes.

Time for the proposal seminar should be scheduled simultaneously for each class so that students can be motivated to submit their research proposal more quickly. SB-IPB also needs to make regular meetings between the supervisors and the students (e.g. once in two weeks) after the completion of the lectures; therefore, the progress of the thesis writing can be monitored earlier so that the supervisors can provide the right solutions from the beginning. With the existence of a definite schedule, meetings between students and their supervisors can be conducted easier.

Nurmianto and Siswanto (2006) say that improving the performance of employees can be performed by improving the operational process. Bureaucratic and administrative processes in thesis writing and learning activities need to be simplified. The division between administrative line for students who graduate on time/ 
smoothly and that for students approaching DO needs to be done. The number of academic human resources is currently only seven people, and based on their experience, the students who completed their thesis writing earlier were hampered by lack of academic human resources, and the academic management gave priority to the students approaching their DO. This caused problems to the students, who already completed their thesis, and this kind of work system became ineffective; therefore, it is necessary to propose a number of new academic staff.

\section{CONCLUSIONS AND RECOMMENDATIONS}

\section{Conclusions}

Based on the analysis on the factors that influenced the learning success of the Master program students of IPB the Business School, it can be concluded that the employment status is a single indicator that reflects the characteristics of the students of the Master program of IPB Business School in influencing their thesis writing process and indirectly gives an impact on their success of study. The process of thesis writing is significantly reflected by the physical condition, motivation, suitability of interest areas, administrative process, academic policy, and supervisor role. The indicators that play a dominant role in the process of thesis writing include the suitability of areas of interest and administrative process.

\section{Recommendations}

The academic division is expected to be more active in controlling students who are in the process of their thesis writing, especially in the class where the majority of the students work fulltime to support their learning success better. Thus, it is expected that the business process of SB-IPB can also run better. Further research is required to analyze factors that influence the success of study based on the business process on the supporting functions such as the asset management, facility and infrastructure, human resource management, and financial management. In addition, the measurement of output alone is not sufficient to discuss how much the university contributes to the community. Further research is also required to analyze the outcome of the students graduating from SB-IPB in improving the performance of the company or their business after graduating from SB-IPB.

\section{REFERENCES}

Abiddin NZ, Ismail A. 2011. Attrition and completion issues in postgraduate studies for student development. International Review of Social Sciences and Humanities 1(1): 15-29.

Bain S, Fedynich LV, Knight M. 2009. The successful graduate student: A review of the factors for success. Journal of Academic \& Business Ethics 1(3): 1-9.

Barnes BJ. 2010. The nature of exemplary doctoral advisors' expectations and the ways they may influence doctoral persistence. Journal of College Student Retention: Research, Theory \& Practice 11(3): 323-343.

Frihadian RZ,PurwitoA, Sitanggang IS.2016.Perbaikan kualitas berkelanjutan penyelenggaraan akademik program sarjana ilmu komputer FMIPA IPB. Jurnal Aplikasi Bisnis dan Manajemen 2(2):207-217.

Ghozali I. 2008. Structural Equation Modeling Metode Alternatif dengan Partial Least Square (PLS). Semarang: UNDIP.

Guillory CW. 2008. A multilevel discrete time hazard model of retention data in higher education [Disertasi]. Louisiana: Louisiana State University.

Jinarek V. 2010. Potential predictors of timely completion among dissertation research students at an Australian Faculty of Sciences. International Journal of Doctoral Studies 8 (63):83-104.

Jones M. 2013. Issues in doctoral studies - Forty years of journal discussion: where have we been and where are we going. International Journal of Doctoral Studies 8 (6):83-104.

Kearns H, Gardiner M, Marshall K. 2008. Innovation in $\mathrm{PhD}$ completion: The hardy shall succeed (and be happy!). Higher Education Research \& Development 27:77-89.

Kusnendar K, Suwachid, Wijayanto DS. Analisis penghambat penyelesaian studi mahasiswa S1 Program Studi Pendidikan Teknik Mesin Jurusan Pendidikan Teknik dan Kejuruan Fakultas Keguruan dan Ilmu Pendidikan. Jurnal Universitas Sebelas Maret 1(3): 1-12.

Manathunga C. 2005. Early warning signs in postgraduate research education: a different approach to ensuring timely completions. Teaching in Higher Education 10: 219-233.

Mircea M, Andreescu AI. 2011. Using cloud computing in higher education: A strategy to improve 
agility in the current financial crisis. Journal of Communications of the IBIMA 2011(2011): 1-15. doi: 10.5171/2011.875547.

Laila RAN. 2016. Evaluasi jasa pendidikan program pascasarjana di Institut Pertanian Bogor [tesis]. Bogor: Program Pascasarjana IPB.

Nasution MN. 2010. Manajemen Perubahan. Jakarta: Ghalia Indonesia.

Nurmianto E, Siswanto N. 2006. Perancangan penilaian kinerja karyawan berdasarkan kompetensi spencer dengn metode analytical hierarchy process. Jurnal Teknik Industri 8(1): 40-53.

Oonyu JC, Wamala R. 2012. Completion time dynamics for master's and doctoral studies at Makerere University. Contemporary Issues In Education Research-Second Quarter 5(2):140-146.

Pitchforth J, Beames S, Thomas A, Falk M, Farr C, Gasson S, Thamrin SA, Mengersen K. 2012. Factors affecting timely completion of a Phd: A complex systems approach. Journal of the Scholarship of Teaching and Learning 12(4): 124-135.

Sevilla CG, Ochave JA, Punsalan TG, Regala BP, Uriarte GG. 1993. Pengantar Metode Penelitian. Tuwu A, penerjemah. Jakarta: UI Pr. Terjemahan dari An Introduction to Reasearch Methods.

Siregar F. 2015. Kajian waktu penyelesaian studi mahasiswa sekolah pascasarjana IPB dan implikasi manajerialnya [Tesis]. Bogor: Program Pascasarjana IPB.

Spaulding LS, Szapkiw AJR. 2012. Hearing their voices: Factors doctoral candidates attribute to their persistence. International Journal of Doctoral Studies 7:199-219.

Sujova A, Rajnoha R. 2012. The management model of strategic change based on process principles. Procedia-Social and Behavioral Sciences 62(24): 1286-1291.

Swartling D, Poksinska B. 2013. Management initiation of continuous improvement from a motivational perspective. Journal of Applied Economics and Business Research 3(2): 81-94.

Trail C, Reiter HI, Bridge M, Stefanowska P, Schmuck M, Norman G. 2006. Impact of field of study, college and year on calculation of cumulative grade point average. Advances in Health Sciences Education 13: 253-261.

Webometrics. 2016. Ranking web of business schools in indonesia.http://business-schools.webometrics. info/en/Asia/Indonesia\%20.[16September 2016].

Wibowo MG. 2013. Analisis efisiensi program studi dan fakultas pada Universitas Islam Negeri Sunan Kalijaga. Jurnal EKBISI 7(2): 261-279.

Yunis R, Surendro K. 2009. Perancangan model enterprise architecture dengan TOGAF architecture development method. Di dalam: Seminar Nasional Aplikasi Teknologi Informasi (SNATI); Yogyakarta, 20 Juni 2009. Yogyakarta: UII. hlm 25-31.

Yudhaningsih R. 2011. Peningkatan efektivitas kerja melalui komitmen, perubahan dan budaya organisasi. Jurnal Pengembangan Humaniora 11(1): 40-50. 